\title{
ANALISIS POLA RUTE DISTRIBUSI PAKET PADA PT.POS INDONESIA (PERSERO) AMBON DENGAN MENGGUNAKAN METODE TRAVELLING SALESMAN PROBLEM DAN DIFFERENTIAL EVOLUTION
}

\author{
D. B. Paillin \\ Program Studi Teknik Industri, Fakultas Teknik Universitas Pattimura, Ambon \\ Meisly Tamaela \\ Program Studi Teknik Industri, Fakultas Teknik Universitas Pattimura, Ambon
}

\begin{abstract}
ABSTRAK
PT. POS Indonesia (PERSERO) Ambon merupakan badan usaha milik Negara yang bergerak di layanan pos dan distribusi. Proses distribusi terbagi menjadi 2 proses yaitu proses distribusi surat dan distrbusi paket (barang). Dalam proses distribusi paket dilakukan pada 5 kecamatan yang ada di Kota Ambon. Dengan luasnya rute distribusi yang harus dilalui petugas pos dalam mendistribusikan paket maka perlu dilakukan analisis pola rute pendistribusian paket terpendek dari semua rute yang ada sehingga memperoleh jarak dan waktu tempuh yang optimal.Dalam meneyelesaikan permasalahan perusahaan dapat dilakukan dengan menggunakan metode Travelling Salesman Problem dan metode Differetcial Evolution. Metode Travelling Salesman Problem merupakan sebuah metode yang digunakan untuk meminimasi biaya distribusi dengan cara mencari jarak dan rute terdekat, waktu tercepat dan biaya yang minimal dan metode Differential Evolution digunakan untuk menemukan solusi terbaik dari semua solusi yang ada.Hasil yang diperoleh dengan menggunakan metode Travelling Salesman Problem untuk jalur dalam kota adalah 58,81 Km dengan penghematan jarak sebesar 22,39\% dan total jarak untuk jalur luar kota adalah 74,65 km dengan penghematan jarak sebesar 13,56\%. Hasil yang diperoleh dengan menggunakan metode Differential Evolution adalah 54,71 km untuk jalur dalam kota dengan penghematan jarak sebesar 27,80\% dan 71,74 km untuk jalur luar kota dengan penghematan jarak 16,93\%.
\end{abstract}

Kata Kunci : Distribusi, Travelling Salesman Problem, Differential Evolution, Minimasi Biaya

\begin{abstract}
PT. POS Indonesia (Persero) as state-owned enterprises serve posts and distribution in Indonesia. The distribution process is divided into two processes those are letter distribution and package distribution. The packages are distributed to five sub-districts in Ambon city. By the extensive of distribution region served by the postmen, it is necessary to find the optimum route and distance to distribute the package. Travelling solution problem (TSP) and Differential Evolution are applied to minimize distribution cost by searching for the closest both route and distance, the fastest time and the minimum cost. The results run with TSP are for the total distance for the closest route in-region is $58.81 \mathrm{Km}$ or $22.39 \%$ saves while for the total distance for the closest route out-region is $74.65 \mathrm{~km}$ or $13.56 \%$ saves. Whilst applying differential evolution, it obtains $54,71 \mathrm{Km}$ or $27.8 \%$ saves for in-region route while $71,74 \mathrm{Km}$ or $16.93 \%$ save for outregion route.
\end{abstract}

Kata Kunci : Distribution, Travelling Salesman Problem, Differential Evolution, Minimizing

\section{PENDAHULUAN}

Transportasi merupakan hal yang penting bagi suatu perusahaan karena dengan adanya proses ini maka barang atau produk bisa sampai kepada konsumen. Pendistribusian barang yang dilakukan dari beberapa tempat tujuan yang berbeda inilah yang menyebabkan adanya masalah, hal ini dikarenakan akan menimbulkan beberapa jalur distribusi yang jarak dan waktu tempuh yang lama.

Perusahaan yang juga berhubungan erat dengan proses distribusi ialah PT. POS Indonesia (PERSERO) Ambon. PT. POS Indonesia (PERSERO) Ambon merupakan sutu badan usaha milik negara yang bergerak di bidang layanan pos baik itu surat. Dalam proses pengiriman pada PT. POS Indonesia (PERSERO) Ambon terdapat tiga jenis pengiriman yaitu; paket express, paket kilat khusus dan paket biasa. Pengiriman dengan menggunakan paket express membutuhkan waktu pengiriman sehari dengan menggunakan transportasi udara. Paket kilat khusus dibutuhkan waktu 3-4 hari untuk paket yang dikirim dapat ditrima, peket kilat khusus juga menggunakan jasa transpportasi udara 
hanya saja biaya yang dikeluarkan lebih murah bila dibandingkan dengan paket express. Dan terakhir paket biasa membutuhkan 2-3 minggu untuk barang dapat diterima oleh pelanggan hal ini dikarenakan proses pengiriman yang menggunakan jasa laut yaitu kapal.

Dengan menggunakan jasa kapal yang tentunya ongkos/ biaya yang dikeluarkan lebih murah ketimbang paket express dan paket kilat khusus. Biasanya barang yang dikirim adalah barang dengan ukuran besar, barang yang mudah pecah dan barang yang dilarang bila ingin menggunakan jasa udara dalam hal ini ialah pesawat. Dengan besarnya ukuran barang maka untuk paket biasa digunakan mobil dari perusahaan untuk mengangkut barang yang dikirim untuk diantarkan ke setiap tempat tujuan yang ada dalam wilayah Ambon. Jumlah kendaraan yang disediakan perusahaan adalah 2 kendaraan dimana kapasitas setiap kendaraan dapat menampung maksimal 80 paket dengan ukuran paket yang besar dan 100 untuk ukuran paket yang kecil. Waktu yang ditempuh bagi petugas pos adalah 7-8 jam /hari.

Proses pendistribusian yang biasa dilalui oleh petugas PT. POS Indonesia (PERSERO) Ambon adalah seluruh Kota Ambon tepatnya 5 Kecamatan diantaranya Kecamatan Leitimur Selatan, Kecamatan Nusaniwe, Kecamatan Sirimau, Kecamatan Baguala, dan Kecamatan Teluk Ambon dengan proses distribusi yang dilakukan dengan membagi jalur yaitu jalur dalam Kota dengan tujuan Karpan, Rijali, Pandan Kasturi, Soya, Waihoka, Batu Gajah, Ahusen, Honipopu, Uritetu, Waihaong, Urimesing, Kudamati, Benteng, Seilale, Amahusu, Silale, Latuhalat, Hatalai, Naku, Kilang, Ema serta Batu Merah dan untuk jalur dalam kota terdiri dari Galala, Hative Kecil, Halong, Latta, Lateri, Passo, Negeri Lama, Nania, Waiheru, Poka, Tihu, Waiyame, Hative Besar, Tawiri, Laha, Hunuth, Hukurila, Leahari, Rutong, dan Hutumuri. Dengan banyaknya rute yang harus dilalui perusahaan maka perusahaan harus tepat dalam menentukan rute yang optimal sehingga proses distribusi tidak dilakukan berdasarkan keinginan supir atau petugas pos dan juga dengan adanya rute yang optimal maka tidak akan berpengaruh pada proses distribusi, maka dari itu perlu dilakukan analisis pola rute untuk mendapatkan rute yang optimal.

Dengan adanya permasalahan ini, maka untuk menyelesaikan permasalahan pada PT. POS Indonesia (PERSERO) Ambon dapat dilakukan dengan menggunakan metode Travelling Salesman Problem (TSP) dengan mengimplementasikan metode Differential Evolution. Dimana metode Travelling Salesman Problem (TSP) digunakan untuk meminimasi biaya distribusi dengan cara mencari jarak dan rute terdekat, waktu tercepat dan biaya yang minimal (Utomo, et. Al.2011) dan metode Differential Evolution digunakan untuk menentukan rute terpendek dari semua rute yang ada. Jadi digunakan metode Travelling Salesman Problem dan metode Differential Evolution untuk memperoleh rute terpendek yang optimal.

\section{LANDASAN TEORI \\ Distribusi}

Distribusi merupakan kegiatan yang tidak lepas kaitannya dengan aktifitas memindahkan suatu barang atau material dari perusahaan terkait hingga sampai ke pihak pelanggan akhir. Distribusi merupakan suatu aktivitas penting bagi perusahaan, karena dengan adanya proses ini, produk yang dihasilkan oleh perusahaan dapat disebarkan dan dipasarkan sampai ke konsumen akhir. Untuk memuaskan konsumen, salah satu hal yang dilakukan oleh perusahaan yaitu berusaha mengirimkan produk atau permintaan konsumen dengan tepat. Oleh karena itu proses distribusi juga menjadi proses yang penting bagi perusahaan.

Proses distribusi yang dilakukan dibagi-bagi dalam kelompok-kelompok kendaraan yang akan mengirimkan produk ke pelanggan melalui rute yang ditentukan oleh perusahaan. Agar proses distribusi berjalan lancar maka dibutuhkan suatu perencanaan untuk dapat menentukan jadwal distribusi dan rute kendaraan yang tepat dan sesuai. Beberapa masalah yang terjadi karena penjadwalan dan penentuan rute kendaraan yang kurang tepat yaitu terjadinya keterlambatan dan muncul waktu tunggu karena estimasi waktu layanan mulai kendaraan berangkat sampai bongkar muatan di konsumen tidak sesuai (Walalangi,et. Al.,2012).

\section{Travelling Salesman Problem}

Metode Travelling Salesman Problem adalah sebuah metode yang digunakan untuk meminimasi biaya distribusi dengan cara mencari jarak dan rute terdekat, waktu tercepat dan biaya yang minimal (Paillin \& Sosebeko, 2017). Travelling Salesman Problem dikenal sebagai suatu permasalahan optimasi yang bersifat klasik dan Non Deterministic Polynimial-time Complete (NPC), dimana tidak ada penyelesaian yang paling optimal selain mencoba seluruh kemungkinan penyelesain yang ada. 
Permasalahan ini melibatkan seorang Travelling salesman yang harus melakukan kunjungan sekali pada semua kota dalam sebuah lintasan sebelum dia kembali ke titik awal, sehingga perjalananya dikatakan sempurna.Permasalahan rute terpendek adalah permasalahan untuk menemukan rute terpendek antara titik asal ( initial node) menuju titik tujuan (final node) dalam suatu jaringan jalan. Permasalahan travelling salesman problem adalah model permasalahan yang bertujuan untuk menemukan rute terpendek bagi seorang penjua keliling untuk berkeliling (touring) mengunjungi setiap pelanggannya sebanyak satu kali. (eka,2012). Adapun beberapa metode penyelesaian dari penelitian dalam metode Travelling Salesman Problem (TSP) adalah sebagai berikut :

1. Metode Branch and Bound

2. Metode Nearest Neighbor

3. Simulated Annealing

\section{Branch and Bound}

Algoritma Branch and bound diusulkan pertama kali oleh A. Land dan G.Doig pada tahun 1960. Sebenarnya metode ini dibuat untuk pemograman linier (linier programming). Namun kenyataanya metode ini mampu menyelesaikan permasalahan seperti Travelling Salesman Problem (TSP) dan beberapa masalah lain. Paillin dan Tupan (2018) menyatakan bahwa metode ini menggunakan pohon pencarian (search tree), setiapsimpul di pohon merupakan representasi dari sejumlah kemungkinan solusi dari Travelling Salesman Problem (TSP). Metode ini hanya dapat digunakan untuk masalah optimasi saja (optimazion problem).

Pendekatan ini terdiri dari dua prosedur utama yaitu branching dan bounding. Branching adalah proses mempartisi masalah yang besar menjadi dua atau lebih masalah kecil (subproblem), sedangkan Bounding adalah proses menghitung batas bawah pada solusi optimal dari subproblem yang bersangkutan. Langkah - langkah untuk penyelesaian Travelling Salesman Problem-nya adalah sebagai berikut:

1. Gambarkan masalahnya dengan digraph $\mathrm{G}=(\mathrm{V}, \mathrm{E})$.

2. Cij yaitu cost pada edge (i,j) dan $\mathrm{Cij}=\infty \mathrm{jika}(\mathrm{i}, \mathrm{j}) \varepsilon \mathrm{E}$.

3. Mengunakan metode Branch and Bound untuk membangun ruang solusi pohon.

4. Menggunakan fungsi pembatas untuk menentukan simpul hidup atau simpul mati, dan seterusnya, hingga didapat solusi yang diinginkan.

\section{Differential Evolution}

Differential Evolution (DE) adalah salah satu metaheuristik yang pemakaiannya cukup luas dalam bidang rekayasa ( Prince et al., 2005). Differential Evolution (DE) termasuk metode pencarian stokhastik dan berdasarkan populasi. DE mempunyai kesamaan dengan evolutionary algorithms (EA) yang lain, tetapi berbeda dalam hal informasi jarak dan arah dari populasi yang sekarang digunakan untuk memandu proses pencarian solusi yang lebih baik.

\section{Ide DE}

DE juga didasarkan pada pembangkitan populasi titik-titik untuk mencapai minimum suatu fungsi. DE agak berbeda dengan algoritma EA dalam hal [Engelbrecht, 2007].

Mutase diterapkan dulu untuk membangkitkan vector percobaan (trial vector), yang kemusian akan digunakan dalam proses crossover untuk menghasilkan satu turunan (offspring). Step size dalam mutase tidak disampel dari distribusi populasi yang sudah diketahui.

Dalam DE, step size dalam mutase dipengaruhi oleh perbedaan diantara individu dalam populasi sekarang. Titik-titik ini akan disampling secar rando sebagai titik awal. Kemudian perlu dilakukan pembatasan nilai-nilai (batas atas maaupun batas bawah) dimana kira-kira nilai variable yang dicari akan berada. Pembangkitan populasi awal tentu saja harus memperhatikan batas bawah dan batas atas ini. Setiap vector (dari titik-titik dalam populasi) diberi indeks untuk menandai posisinya. DE membangkitkan titik baru berdasarkan titik yang ada dan selisih antara dua titik dalam populasi. Ini berbeda dengan metoda direct search seperti Nelder Mead yang membangkitkan titik baru dengan cara refleksi atau melakukan sampling dari suatu distribusi tertentu seperti dalam ES.

\section{METODE PENELITIAN}

Pada penelitian ini pengolahan dan analisa data dengan menggunakan Travelling Salesman Problem dengan mengimplementasikan metode Differential Evolution. Metode Travelling Salesman digunakan untuk menentukan rute terpendek dari satu titik ke titik yang lain dan metode Differential Evolution digunakan untuk menentukan rute terpendek dari semua rute yang ada. 
Berikut ini merupakan flowchart dari penelitian ini.

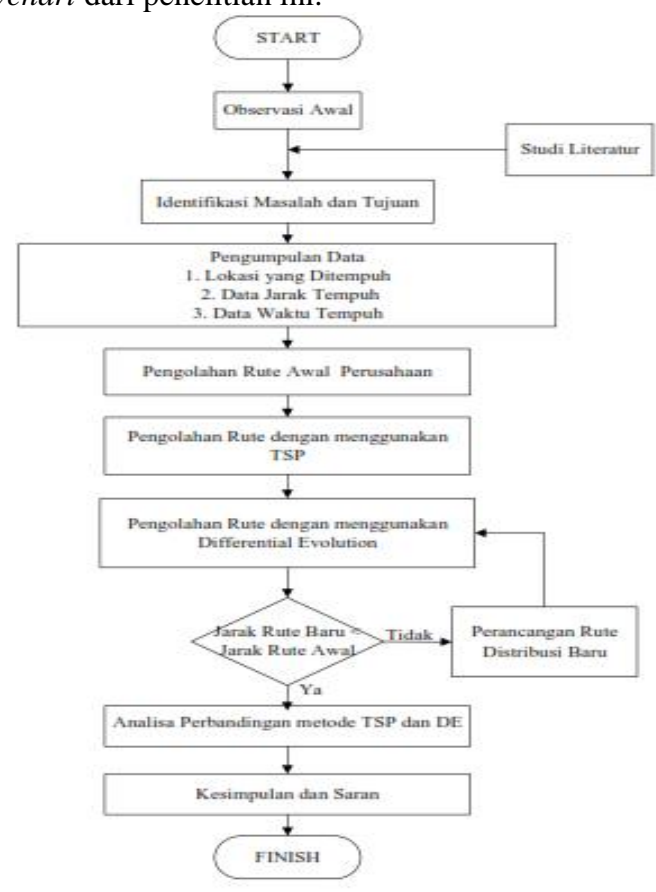

Flowchart Penelitian

\section{HASIL DAN PEMBAHASAN}

\section{Data Jarak Tempuh}

Data jarak tempuh adalah data jarak yang dilalui petugas Pos dalam mendistribusikan paket yang ada. Kendaraan yang digunakan adalah mobil Grand Max Daihatsu. Dengan kapasitas angkut yang dapat menampung maksimal 80 paket dengan ukuran paket yang besar dan 100 untuk ukuran paket yang kecil.

Titik Koordinat Lokasi Pendistribusian Dalam Kota

\begin{tabular}{|c|c|c|c|c|}
\hline NO & KODE & DEPOT & LATITUDE & LONGTUDE \\
\hline 1 & PJM & PT. POS Indonesia Ambon & -3.692952 & 128.221628 \\
\hline 2 & C1 & Karpan & -3.691516 & 128.192797 \\
\hline 3 & C2 & Rijali & -3.689719 & 128.186813 \\
\hline 4 & C3 & Pandan Kasturi & -3.674645 & 128.191724 \\
\hline 5 & C4 & Soya & -3.688504 & 128.233827 \\
\hline 6 & C5 & Waihoka & -3.691382 & 128.202968 \\
\hline 7 & C6 & Batu Gajah & -3.698693 & 128.184984 \\
\hline 8 & C7 & Ahusen & -3.694371 & 128.182274 \\
\hline 9 & C8 & Uritetu & -3.693019 & 128.176771 \\
\hline 10 & C9 & Waihaong & -3.698319 & 128.174991 \\
\hline 11 & C10 & Urimesing & -3.710932 & 128.176736 \\
\hline 12 & C11 & Kudamati & -3.70812 & 128.170372 \\
\hline 13 & C12 & Benteng & -3.705118 & 128.163598 \\
\hline 14 & C13 & Seilale & -3.68814 & 128.118307 \\
\hline 15 & C14 & Amahusu & -3.6971739 & 128.138903 \\
\hline 16 & C15 & Silale & -3.787575 & 128.176999 \\
\hline 17 & C16 & Latuhalat & -3.727851 & 128.104224 \\
\hline 18 & C17 & Hatalai & -3.726795 & 128.217355 \\
\hline 19 & C18 & Naku & -3.724147 & 128.221814 \\
\hline 20 & C19 & Kilang & -3.730658 & 128.232743 \\
\hline 21 & C20 & Ema & -3.682023 & 128.189393 \\
\hline 22 & C21 & Batu Merah & \\
\hline 23 & C22 & & & \\
\hline & & & & \\
\hline
\end{tabular}


Koordinat Lokasi Pendistribusian Luar Kota

\begin{tabular}{|c|c|c|c|c|}
\hline NO & KODE & DEPOT & LATITUDE & LONGTUDE \\
\hline 1 & PJM & PT. POS Indonesia Ambon & -3.692952 & 128.221628 \\
\hline 2 & C1 & Galala & -3.665823 & 128.200578 \\
\hline 3 & C2 & Hative Kecil & -3.66652 & 128.205364 \\
\hline 4 & C3 & Halong & -3.668464 & 128.228156 \\
\hline 5 & C4 & Latta & -3.652874 & 128.234694 \\
\hline 6 & C5 & Lateri & -3.647220 & 128.243837 \\
\hline 7 & C6 & Passo & -3.589520 & 128.252481 \\
\hline 8 & C7 & Negeri Lama & -3.609270 & 128.234343 \\
\hline 9 & C8 & Nania & -3.624958 & 128.234211 \\
\hline 10 & C9 & Waiheru & -3.650963 & 128.214539 \\
\hline 11 & C10 & Poka & -3.651568 & 128.192674 \\
\hline 12 & C11 & Tihu & -3.662439 & 128.187428 \\
\hline 13 & C12 & Waiyame & -3.675877 & 128.137873 \\
\hline 14 & C13 & Hative besar & -3.695873 & 128.103247 \\
\hline 15 & C14 & Tawiri & -3.702293 & 128.094054 \\
\hline 16 & C15 & Laha & -3.630871 & 128.208451 \\
\hline 17 & C16 & Hunuth & -3.736875 & 128.246756 \\
\hline 18 & C17 & Hukurila & 128.267509 \\
\hline 19 & C18 & Leahari & 128.269224 \\
\hline 20 & C19 & C20 & & 128.295140 \\
\hline 21 & & & \\
\hline & & & -3.701403 & \\
\hline
\end{tabular}

Matriks Data Jarak Tempuh Jalur Dalam Kota

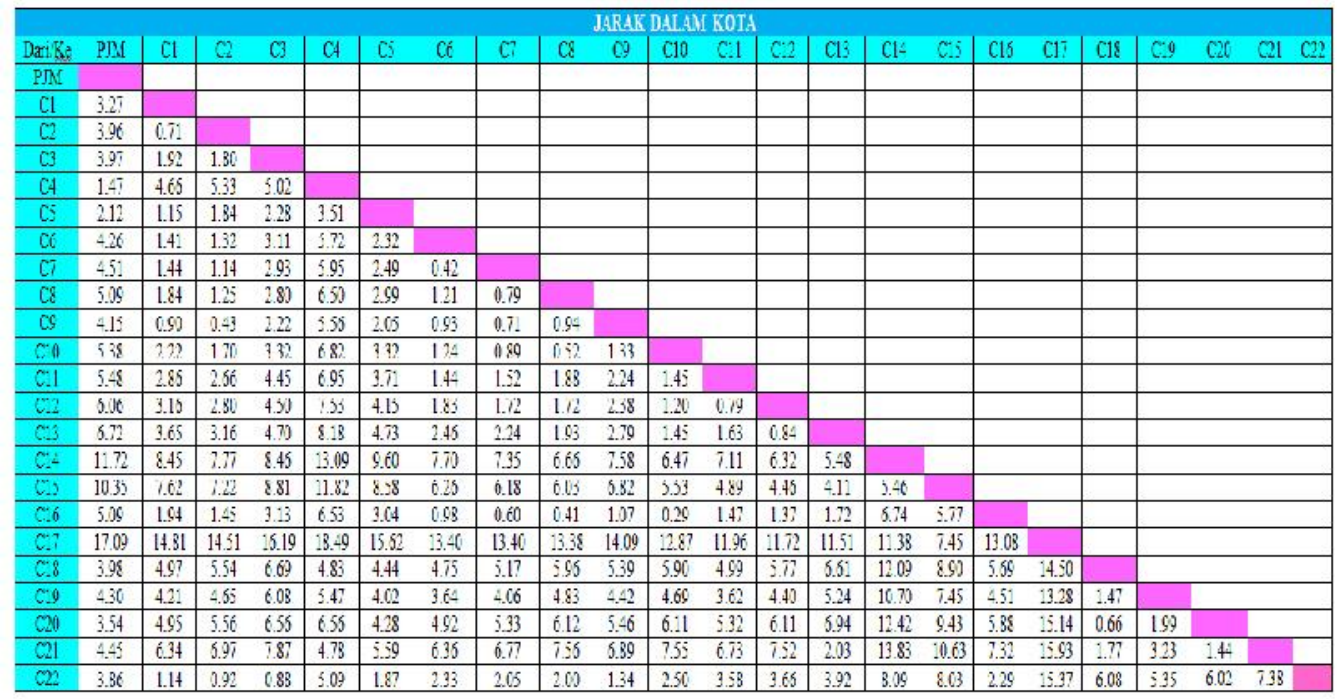


Matriks Data Jarak Tempuh Jalur Dalam Kota

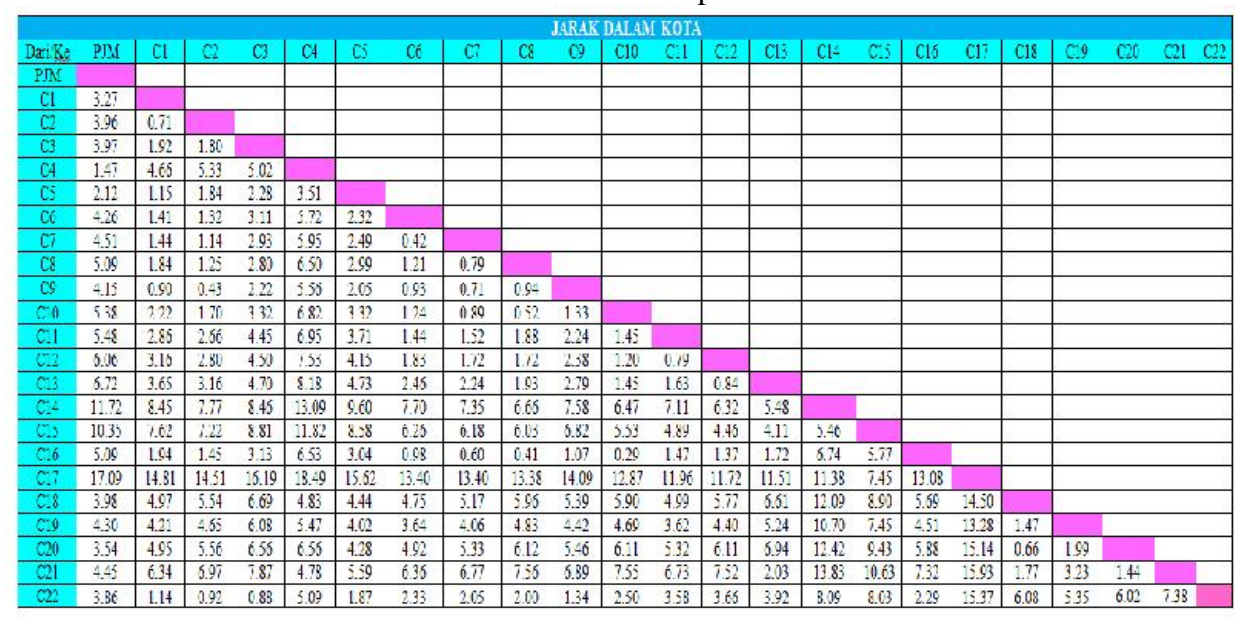

Matriks Data Jarak Tempuh Jalur Dalam Kota

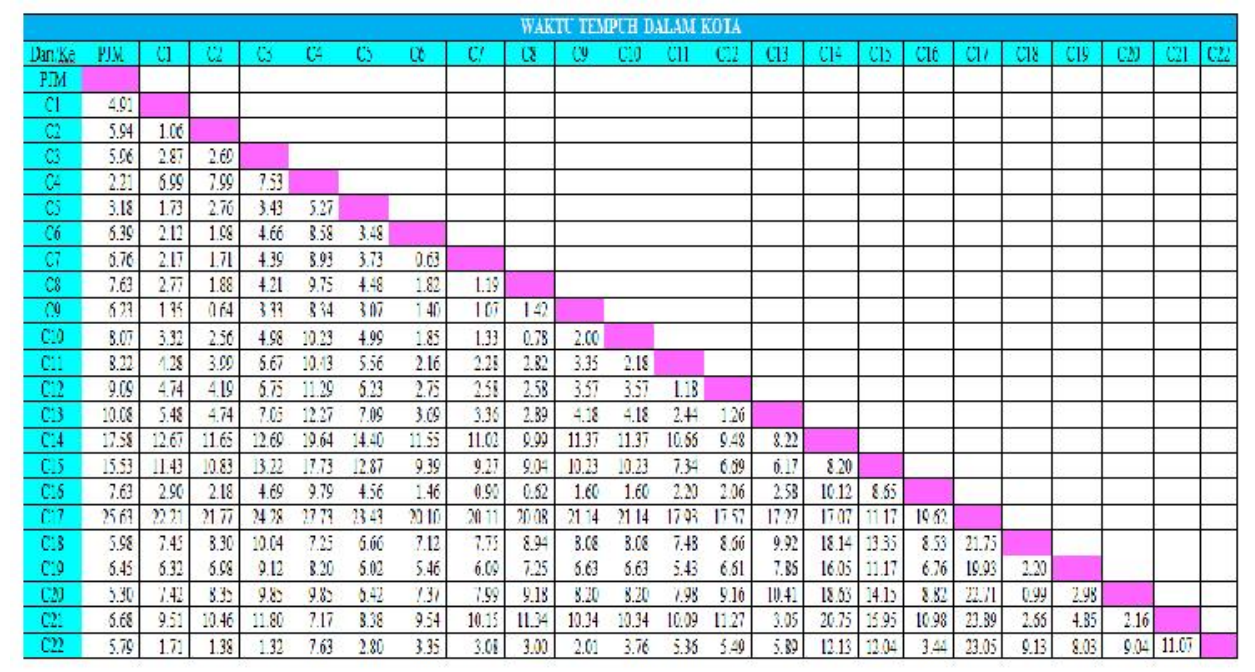

Matriks Waktu Tempuh Jalur Luar Kota

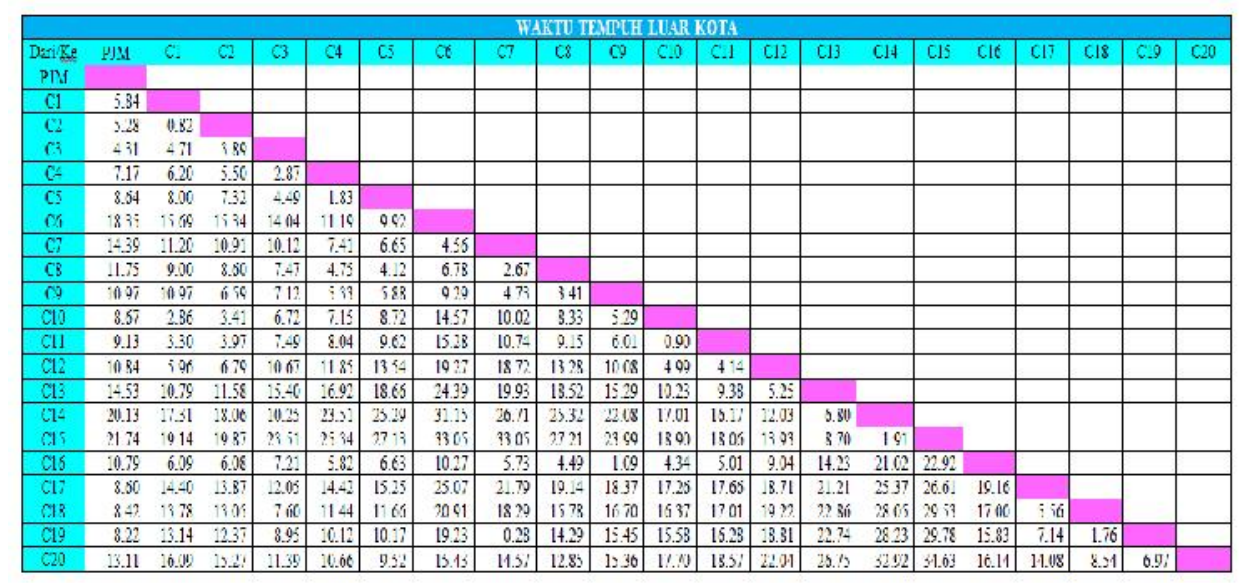




\section{Rute Awal Perusahaan}

Hasil Pengolahan Rute Awal Perusahaan

\begin{tabular}{|c|r|l|c|c|}
\hline \multirow{2}{*}{ No } & Jalur & \multicolumn{1}{|c|}{ Rute Distribusi } & \multicolumn{2}{|c|}{ Jumlah } \\
\cline { 3 - 5 } & \multicolumn{1}{|c|}{$\begin{array}{c}\text { Jarak } \\
\text { Dalam } \\
1\end{array}$} & $\begin{array}{l}\text { PJM-C17-C14-C15-C13-C12-C16-C11-C10-C9-C8-C7-C6- } \\
\text { C1- C5-C4-C19-C18-C20-C21-C22- C3-C2-PJM }\end{array}$ & 75.78 & 113.67 \\
\hline 2 & Luar Kota & $\begin{array}{l}\text { PJM-C1-C2-C3-C4-C5-C6-C7-C8-C9-C10-C11-C12- } \\
\text { C13-C14-C15-C16-C17-C18-C19-C20-PJM }\end{array}$ & 86.37 & 129.56 \\
\hline
\end{tabular}

Hasil dan Analisa Rute dengan Menggunakan Travelling Salesman Problem (Branch and Bound) Pada PT.POS Indonesia (PERSERO) Ambon.

Dalam mencari rute terpendek dari suatu aktivitas distribusi dapat dilakukan dengan menggunakan metode Branch and Bound. Dalam mecari rute terpendek dari metode Branch and Bound ini dapat dilakukan dengan menggunakan aplikasi software WinQSB.

\section{Rute Jalur Dalam Kota}

\begin{tabular}{|c|c|c|c|c|c|c|c|}
\hline 07-19-2018 & From Node & Connect To & Distance/Cost & & From Node & Connect To & Distance/Cost \\
\hline 1 & एJM & C4 & 1.47 & 13 & C14 & C13 & 5.40 \\
\hline 2 & C4 & C3 & 5.02 & 14 & CI3 & C 10 & 1.45 \\
\hline 3 & CJ & C22 & 0.00 & 15 & C10 & Co & 0.52 \\
\hline 1 & $\mathrm{C} 22$ & C9 & 1.31 & 16 & C8 & $\mathrm{C} 2$ & 1.25 \\
\hline 5 & Co & CG & 0.93 & 17 & C2 & C1 & 0.71 \\
\hline 6 & C6 & C7 & 0.12 & 18 & CI & C5 & 1.15 \\
\hline 7 & r.7 & r:16 & n $\mathrm{F}$ & 19 & r.:. & r:19 & $4 n ?$ \\
\hline $\mathbf{8}$ & C16 & CII & 1.17 & 20 & CIg & C18 & 1.17 \\
\hline 9 & r.11 & r.12 & n 79 & 21 & r:18 & r.2n & n f6 \\
\hline TU & 572 & L7b & 4.46 & 22 & L̈ZU & Ë21 & 1.44 \\
\hline 11 & r.15 & r:17 & 745 & 23 & r.21 & P.IM & 445 \\
\hline \multirow[t]{2}{*}{12} & L1\% & 274 & 11.38 & & & & \\
\hline & $\begin{array}{c}\text { Total } \\
\text { [Result }\end{array}$ & $\begin{array}{c}\text { Minimal } \\
\text { from }\end{array}$ & $\begin{array}{c}\text { Traveling } \\
\text { Branch }\end{array}$ & $\begin{array}{c}\text { Distance } \\
\text { and }\end{array}$ & $\begin{array}{l}\text { or Cost } \\
\text { Bound }\end{array}$ & $\begin{array}{c}- \\
\text { Method] }\end{array}$ & 50.01 \\
\hline
\end{tabular}

Hasil Pengolahan Data Jalur Dalam Kota

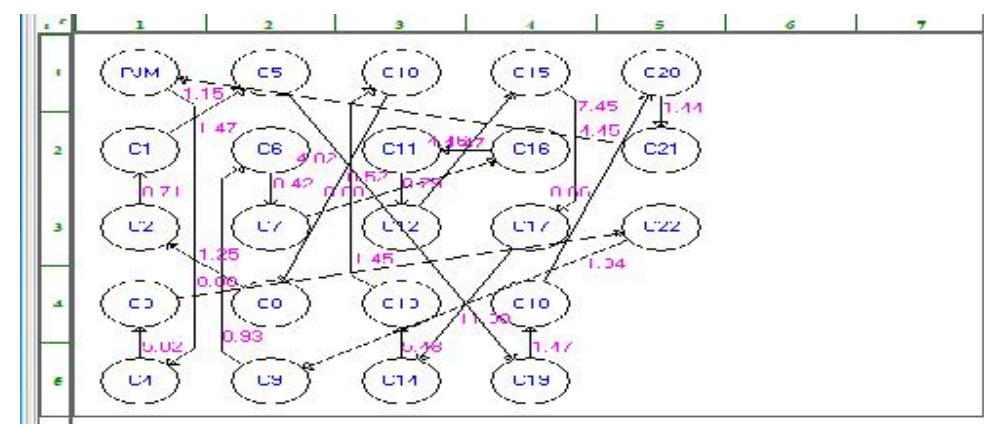

Graph Solution Jalur Dalam Kota

Berdasarkan dengan tabel diatas dan gambar diatas, dapat dilihat bahwa urutan rute distribusi terpendek yang dapat dilalui petugas Pos adalah PJM - C4 - C3 - C22 - C9 - C6 - C7 - C16 - C11 - C12 C15 - C17 - C14 - C13 - C10 - C8 - C2 - C1 - C5 - C19 - C18 - C20 - C21 - PJM dengan total jarak tempuh $58.81 \mathrm{Km}$ dan waktu tempuh adalah 88.22 menit. Rute-rute tersebut jika dilihat berdasarkan alamat maka perjalanan yang ditempuh petugas Pos antara lain PT.POS Indonesia (PERSERO) Ambon - Soya - Pandan Kasturi - Batu Merah - Uritetu - Batu Gajah - Ahusen - Silale Urimesing - Kudamati - Amahusu - Latuhalat - Seilale - Benteng - Waihaong - Honipopu - Rijali Karpan - Waihoka - Naku - Hatalai - Kilang - Ema - PT.POS Indonesia (PERSERO). 
Rute Jalur Luar Kota

\begin{tabular}{|c|c|c|c|c|c|c|c|}
\hline 07-10-2018 & Fium Nude & Curinedl Tu & Dislarice/Cust & & Fium Nude & Curnecl Tu & Dislarice/Cust \\
\hline 1 & PJM & LZ2 & 3.52 & 12 & Li & L6 & 3.04 \\
\hline 2 & C2 & C1 & 0.55 & 13 & C6 & C8 & 4.52 \\
\hline 3 & r.1 & r.15 & 1276 & 14 & r. & r.5 & 275 \\
\hline 4 & C15 & C14 & 1.27 & 15 & C5 & C4 & 1.22 \\
\hline 5 & CI4 & CI3 & 4.53 & 16 & C4 & C3 & 1.92 \\
\hline 6 & C13 & C12 & 3.5 & 17 & C3 & C20 & 7.59 \\
\hline 7 & C12 & C11 & 2.76 & 18 & $\mathrm{C} 20$ & C18 & 5.69 \\
\hline 8 & C11 & C10 & 0.6 & 19 & C18 & C19 & 1.17 \\
\hline 9 & C10 & C16 & 2.89 & 20 & C19 & C17 & 4.76 \\
\hline 10 & C16 & C9 & 0.73 & 21 & C17 & PJM & 5.73 \\
\hline \multirow[t]{3}{*}{11} & C9 & C7 & 3.15 & & & & \\
\hline & Tulal & Mirnimal & Traveliny & Dislarice & ut Cust & $=$ & 74.65 \\
\hline & IHesult & trom & Branch & and & Bound & Method] & \\
\hline
\end{tabular}

Hasil Pengolahan Data Jalur Luar Kota

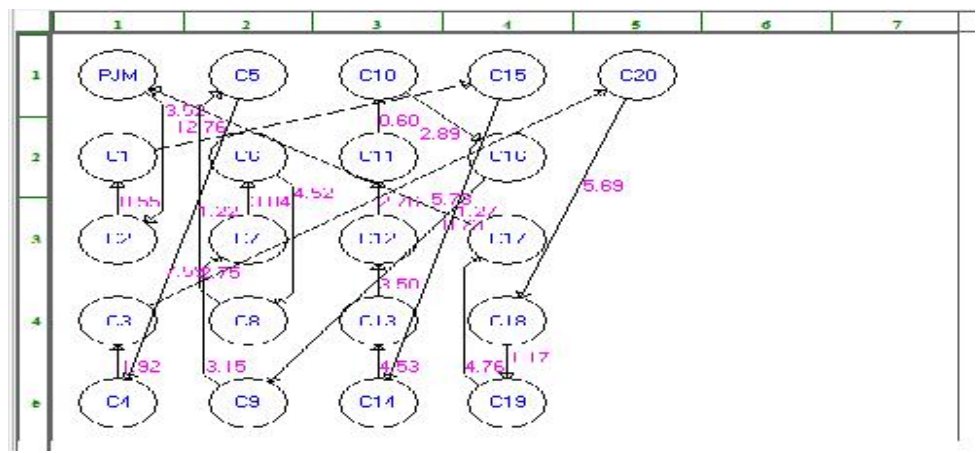

Graph Solution Jalur Luar Kota

Berdasarkan dengan tabel diatas dan gambar diatas dapat dilihat bahwa solusi yang didapat dari hasil pengolahan data WinQSB menunjukkan rute teroendek yang dapat dilalui petugas Pos. Rute yang diperoleh antara lain PJM - C2 - C1 - C15 - C14 - C13 - C12 - C11 - C10 - C16 - C9 - C7 - C6 C8 - C5 - C4 - C3 - C20 - C18 - C19 - C17 - PJM. Jika rute ini dilihat berdasarkan alamat maka rute tersebut antara lain PT. POS Indonesia (PERSERO) Ambon - Hative Kecil - Galala - Laha - Tawiri - Hative Besar - Waiyame - Tihu - Poka - Hunuth - Waiheru - Negeri Lama - Passo - Nania - Lateri Latta - Halong - Hutumuri - Leahari - Rutong - PT. POS Indonesia (PERSERO) Ambon dengan total jarak yang ditempuh adalah $74.65 \mathrm{Km}$ dengan waktu tempuh adalah 119.96 menit.

\section{Hasil dan Analisa dengan Menggunakan Metode Differential Evolution}

\section{Rute Jalur Dalam Kota}

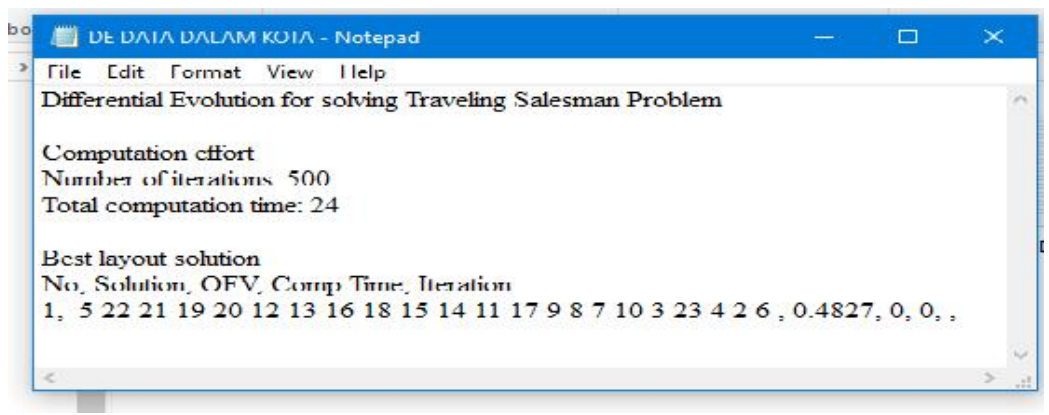

Solusi Rute Jalur Dalam Kota

Berdasarkan gambar diatas maka solusi rute terbaik dimulai dari PT.POS Indonesia (PERSERO) Ambon - Soya - Ema - Kilang - Hatalai - Naku - Urimesing - Kudamati - Amahusu Latuhalat - Seilale - Benteng - Waihaong - Silale - Honipopu - Batu Gajah - Uritetu - Rijali - Batu Merah - Pandan Kasturi - Karpan Waihoka. Dengan total jarak tempuh adalah 54,71 Km dan waktu tempuh yang ditempuh adalah 82,07 menit. 


\section{Rute Jalur Luar Kota}

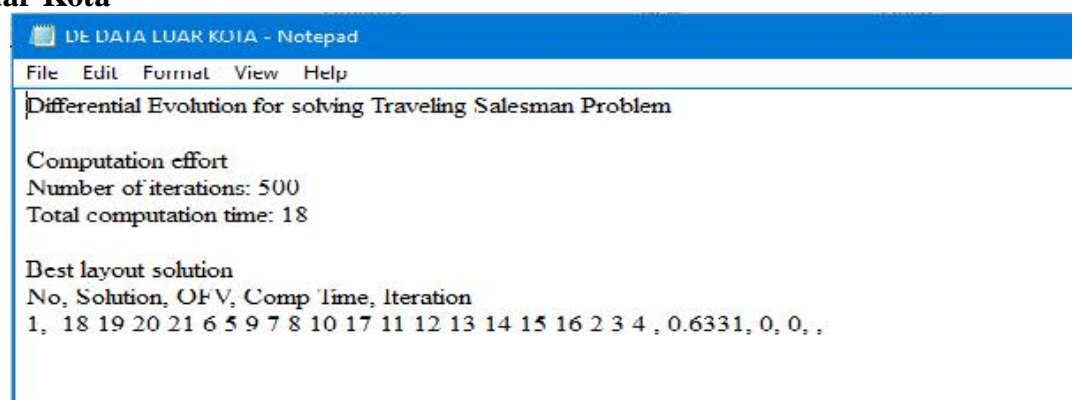

Solusi Rute Jalur Luar Kota

Berdasarkan gambar solusi rute diatas maka urutan rute terbaik berdasarkan metode DE adalah PT. POS Indonesi (PERSERO) Ambon - Hukurila - Leahari - Rutong - Hutumuri - Lateri - Latta - Nania Passo - Negeri Lama - Waiheru - Hunuth - Poka - Tihu - Waiyame - Hative Besar - Tawiri - Laha Galala - Hative Kecil - Halong - PT. POS Indonesia (PERSERO) Ambon. Dengan jarak tempuh adalah $71.74 \mathrm{Km}$ dan waktu tempuh adalah 107.61 menit.

\section{Perbandingan Rute Awal Perusahaan dan Travelling Salesman Problem (Branch and Bound)}

\begin{tabular}{|c|c|c|c|c|}
\hline \multirow[b]{2}{*}{ No } & \multirow[b]{2}{*}{ Jalur } & \multirow[b]{2}{*}{ Rute Distribusi } & \multicolumn{2}{|c|}{ Jumlah } \\
\hline & & & $\begin{array}{l}\text { Jarak } \\
(\mathrm{K} \mathbf{m})\end{array}$ & $\begin{array}{l}\text { Waktu } \\
\text { (Menit) }\end{array}$ \\
\hline 1 & $\begin{array}{l}\text { Dalam Kota } \\
\text { (Rute Awal } \\
\text { Perusahaan) }\end{array}$ & $\begin{array}{l}\text { PJM-C17-C14-C15-C13-C12- } \\
\text { C16-C11-C10-C9-C8-C7-C6- C1- } \\
\text { C5-C4-C19-C18-C20-C21- C22-C3- } \\
\text { C2-PJM }\end{array}$ & 75.78 & 113.67 \\
\hline 2 & $\begin{array}{r}\text { Dalam Kota } \\
\text { (TSP) }\end{array}$ & $\begin{array}{ll}\text { PJM-C4-C3-C22-C9-C6-C7- } & \text { C16- } \\
\text { C11-C12-C15-C17-C14- } & \text { C13- } \\
\text { C10-C8-C2-C1-C5-C19- } & \text { C18- } \\
\text { C20-C21-PJM } & \end{array}$ & 58.81 & 88.22 \\
\hline 3 & $\begin{array}{l}\text { Luar Kota } \\
\text { (Rute Awal } \\
\text { Perusahaan) }\end{array}$ & $\begin{array}{l}\text { PJM-C1-C2-C3-C4-C5-C6- } \\
\text { C7-C8-C9-C10-C11-C12-C13- } \\
\text { C14-C15-C16-C17-C18-C19-C20- } \\
\text { PJM }\end{array}$ & 86.37 & 129.56 \\
\hline 4 & $\begin{array}{l}\text { Luar Kota } \\
\text { (TSP) }\end{array}$ & $\begin{array}{l}\text { PJM-C2-C1-C15-C14-C13- } \\
\text { C12-C11-C10-C16-C9-C7-C6- C8- } \\
\text { C5-C4-C3-C20-C18-C19- C17-PJM }\end{array}$ & 74.65 & 111.96 \\
\hline
\end{tabular}

Berdasarkan data pada tabel diaats juga dapat dilakukan selisih perbandingan antara jarak perusahaan dan jarak dengan menggunakan metode Travelling Salesman Problem. Hasil Perbandingan dapat dilihat sebagai berikut:

A. Jalur Dalam Kota

$$
\begin{aligned}
& \frac{\text { Jarak Perusahaan-Jarak TSP }}{\text { Jarak Perusahaan }} \times 100 \%=\frac{75.78-58.81}{75.78} \times 100 \%=22.39 \% \\
& \frac{\text { Waktu P. -WaktuTSP }}{\text { Waktu Perusahaan }} \times 100 \%=\frac{113.67-88.22}{113.67} \times 100 \%=22.38 \%
\end{aligned}
$$


B. Jalur Luar Kota

$$
\begin{gathered}
\frac{\text { Jarak Perusahaan-Jarak TSP }}{\text { Jarak Perusahaan }} \times 100 \%=\frac{86.37-74.65}{86.37} \times 100 \%=13.56 \% \\
\frac{\text { Waktu P. }- \text { Waktu TSP }}{\text { Waktu Perusahaan }} \times 100 \%=\frac{129.56-111.96}{129.56} \times 100 \%=13.58 \%
\end{gathered}
$$

Dari hasil perhitungan datas, maka selisih penghematan jarak antara perusahaan dan jarak dengan menggunakan metode Travelling Salesman Problem untuk jalur dalam kota sebesar $28.85 \%$ dengan penghematan waktu sebesar $22.38 \%$ dan presentasi penghematan jarak untuk jalur luar kota sebesar $13.56 \%$ serta penghematan waktu sebsar $13.58 \%$.

Perbandingan Rute Awal Perusahaan dan Differential Evolution

Berdasarkan dengan hasil yang telah diperoleh dengan menggunakan software DE maka yang dilakukan selanjutnyan adalah membandingkan hasil rute yang diperoleh dengan rute yang digunakan oleh perusahaan. Hasil perbandingan dapat dilihat pada tabel berikut ini:

\begin{tabular}{|c|c|c|c|c|}
\hline & & & \multicolumn{2}{|c|}{ Jumlah } \\
\hline No & Jalur & Rute Distribusi & $\frac{\text { Jarak }}{(\mathrm{K} \mathbf{m})}$ & $\frac{\text { Waktu }}{\text { (Menit) }}$ \\
\hline 1 & $\begin{array}{l}\text { Dalam Kota (Rute } \\
\text { Awal Perusahaan) }\end{array}$ & $\begin{array}{l}\text { PJM-C17-C14-C15-C13-C12- } \\
\text { C16-C11-C10-C9-C8-C7-C6-C1- } \\
\text { C5-C4-C19-C18-C20-C21- C22-C3- } \\
\text { C2-PJM }\end{array}$ & 75.78 & 113.67 \\
\hline 2 & $\begin{array}{l}\text { Dalam Kota } \\
\text { (DE) }\end{array}$ & $\begin{array}{l}\text { PJM-C4-C21-C20-C18-C19- } \\
\text { C11-C12-C15-C17-C14-C13-C10- } \\
\text { C16-C8-C7-C6-C9-C2- C22-C3- } \\
\text { C1-C5-PJM }\end{array}$ & 54.71 & 82.07 \\
\hline 3 & $\begin{array}{l}\text { Luar Kota } \\
\text { (Rute Awal } \\
\text { Perusahaan) }\end{array}$ & $\begin{array}{l}\text { PJM-C1-C2-C3-C4-C5-C6- } \\
\text { C7-C8-C9-C10-C11-C12-C13- } \\
\text { C14-C15-C16-C17-C18-C19-C20- } \\
\text { PJM }\end{array}$ & 86.37 & 129.56 \\
\hline 4 & Luar Kota (DE) & $\begin{array}{l}\text { PJM-C17-C18-C19-C20-C5- } \\
\text { C4-C8-C6-C7-C9-C16-C10- } \\
\text { C11-C12-C13-C14-C15-C1-C2-C3- } \\
\text { PJM }\end{array}$ & 71.74 & 107.61 \\
\hline
\end{tabular}

Hasil Perbandingan Rute Perusahaan dan DE

Berdasarkan data pada tabel diatas, maka dapat dilakukan selisih perbandingan antara jarak perusahaan dan jarak dengan menggunakan metode Differencial Evolution. Hasil Perbandingan dapat dilihat sebagai berikut:

A. Jalur Dalam Kota

$$
\begin{gathered}
\frac{\text { Jarak Perusahaan-Jarak DE }}{\text { Jarak Perusahaan }} \times 100 \%=\frac{75.78-54.71}{75.78} \times 100 \%=27.80 \% \\
\frac{\text { WaktuP. }- \text { Waktu DE }}{\text { Waktu Perusahaan }} \times 100 \%=\frac{113.67-82.07}{113.67} \times 100 \%=27.79 \%
\end{gathered}
$$


B. Jalur Luar Kota

$$
\begin{aligned}
& \frac{\text { Jarak Perusahaan-Jarak DE }}{\text { Jarak Porusahaan }} \times 100 \%=\frac{86.37-71.74}{86.37} \times 100 \%=16.93 \% \\
& \frac{\text { Waktu. P. -Waktu DF }}{\text { WaktuPerusahaan }} \times 100 \%=\frac{129.56-107.61}{129.56} \times 100 \%=16.94 \%
\end{aligned}
$$

Dari hasil perhitungan diatas, maka penghematan yang dapat diperoleh bila menggunakan metode Differencial Evolution untuk jalur dalam kota sebesar $27.80 \%$ dengan penghematan waktu sebesar $27.79 \%$. dan presentasi penghematan jarak untuk jalur luar kota sebesar $16.93 \%$ dan penghematan waktu sebesar $16.94 \%$.

\section{Analisa Rute dan Biaya Bahan Bakar}

Penjumlahan total jarak yang di tempuh oleh perusahaan yaitu dilakukan dengan cara menjumlahkan jarak dari awal sampai akhir perjalanan dari masing- masing. Berdasarkan data yang di peroleh maka total jarak yang di dapatkan adalah sebagai berikut:

Perbandingan Jalur Dalam Kota

\begin{tabular}{|r|l|c|c|}
\hline \multicolumn{1}{|c|}{ No } & \multicolumn{1}{|c|}{ Rute } & Jarak $(\mathrm{Km})$ & Total Jarak Tempuh/Minggu \\
\hline 1 & Perusahaan & 75.78 & 454.68 \\
\hline 2 & Travelling Salesman Problem & 58.81 & 352.86 \\
\hline 3 & Differential Evolution & 54.71 & 328.26 \\
\hline
\end{tabular}

Dapat dihitung biaya bahan bakar dari masing- masing rute yang ada. Berikut hasil perhitungan biaya bahan bakar yang ada:

Rute Travelling Salesman Problem

A. Biaya Bahan Bakar/Minggu:

- Total Jaralk Tompuh $x \frac{1}{10} x$ Harga Bahan Balkar (Bonsin)/Litor

$=352,86 \times \frac{1}{10} \times 6450=\mathrm{Rp} .227 .594$

B. Biaya Bahan Bakar/Bulan:

$=$ Total Jarak Tempuh $x \frac{1}{10} x$ Harga Bahan Bakar $x$ Banyaknya Pengsian

dalam satu bulan

$=352,86 \times \frac{1}{10} \times 6450 \times 4=\mathrm{kp} \cdot y 10.318$

Rute Differential Evolution

A. Biaya Bahan Bakar/Minggu

= I'ctal Jarak Tempuh $x \frac{1}{10} \approx$ Harga Bahan Bakar (Bensin) $/$ Liter

$=328,26 \times \frac{1}{10} \times 6450=$ kp. 211.727

B. Biaya Bahan Bakar/Bulan

$$
\begin{aligned}
& =\text { Total Jarak Tempun } x \frac{1}{10} \times \text { Harga Bahan Bakar } x \text { Banyaknya Pengisian } \\
& \text { dalam satu bulan } \\
& =328,26 \times \frac{1}{10} \times 6450 \times 4=\mathrm{Kp} .846 .910
\end{aligned}
$$

Berdasarkan hasil perhitungan diatas dapat disimpulkan bahwa total jarak yang dilalui perusahaan untuk jalur dalam kota yaitu sebesar $454.68 \mathrm{Km} /$ minggu dengan biaya bahan bakar yang telah ditetapkan 
perusahaan sebesar Rp.2.300.000/bulan. Total jarak bila menggunakan metode Travelling Salesman Problem adalah $352.86 \mathrm{Km} / \mathrm{minggu}$ dengan biaya bahan bakar adalah Rp.227.594/minggu dan Rp 910.378/bulan. Dan untuk metode Differential Evolution total jarak yang ditempuh adalah $328.36 \mathrm{Km}$ dengan biaya bahan bakar/minggu adalah Rp. 211.727 dan Rp. 846.910/bulan.

Dengan demikian bila menggunakan dan menerapkan rute dari Differential Evolution maka akan lebih menguntungkan bagi perusahaan baik itu dari segi jarak, waktu tempuh dan biaya bahan bakar.

Perbandingan Jalur Luar Kota

\begin{tabular}{|c|l|c|c|}
\hline No & \multicolumn{1}{|c|}{ Rute } & Jarak $(\mathbf{K m})$ & Total Jarak Tempuh/Minggu \\
\hline 1 & Perusahaan & 86.37 & 518.22 \\
\hline 2 & Travelling Salesman Problem & 74.65 & 447.90 \\
\hline 3 & Differential Evolutiion & 71.74 & 430.44 \\
\hline
\end{tabular}

\section{KESIMPULAN}

Hasil yang diperoleh dengan menggunakan metode Travelling Salesman Problem untuk jalur dalam kota adalah 58,81 Km dengan penghematan jarak sebesar 22,39\% dan total jarak untuk jalur luar kota adalah 74,65 km dengan penghematan jarak sebesar 13,56\%. Hasil yang diperoleh dengan menggunakan metode Differential Evolution adalah $54,71 \mathrm{~km}$ untuk jalur dalam kota dengan penghematan jarak sebesar $27,80 \%$ dan $71,74 \mathrm{~km}$ untuk jalur luar kota dengan penghematan jarak $16,93 \%$.

\section{DAFTAR PUSTAKA}

Aini, Tsana Kamilia, (2017)., Kinerja PT.POS Indonesia (Studi Kasus Pengiriman Paket Pos di Kota Pekanbaru). Universitas Riau.

Eka, (2010)., Penentuan Rute Distribusi Produk Minuman Ringan PT. Coca-Cola Distribution Indonesia DC Pontianak Menggunakan Metode Travelling Salesman Problem. Pontianak: FT-UNTAN.

Fahmi Fuadi Al Akbar \& Sumiati (2013)., Penentuan Rute Distribusi The Botol Menggunakan Metode Traveling Salesman Problem (TSP) Untuk Minimasi Biaya Distribusi.

Munir, Rinaldi., (2006)., Algoritma Branch and Bound, Bandung:Institut Teknologi Bandung.

Moh. Ray Rizaldy, (2007)., Algoritma Branch and Bound Untuk Optimasi Pengiriman Surat Antar Himpunan di ITB. Bandung. Institut Teknologi Bandung.

Paillin, D. B., \& Sosebeko, F. (2017)., Penentuan Rute Optimal Distribusi Produk Nestle Dengan Metode Traveling Salesman Problem (TSP)(Studi Kasus: PT. Paris Jaya Mandiri). Jurnal ARIKA, Vol 11 No. 1, pp. 35-44.

Paillin, D. B., \& Tupan, J. M. (2018)., Pemecahan Travelling Salesman Problem Menggunakan Teknik Branch and Bound dan Cheapest Insertion Heuristic (Studi Kasus: PT. Paris Jaya MandiriAmbon). In Seminar dan Konferensi Nasional IDEC 2018 Surakarta 7-8 Mei.

Santosa, Budi. (2017)., Pengantar Metaheuristik : Implementasi dengan Matlab. Surabaya: ITS Tekno Sains 